\title{
Social Safety Net Pada Program Keluarga Harapan Dalam Meningkatkan Kesejahteraan Keluarga Miskin Di Kota Palembang
}

\author{
M. Robby Kaharudin \\ Universitas Islam Negeri Raden Fatah Palembang \\ Jl. Prof. K.H. Zainal Abidin Fikri, Palembang, Sumatera Selatan \\ Email: muhrobbykaharudin@gmail.com
}

\begin{abstract}
The purpose of this research were to analyze the effectiveness of the implementation of $\mathrm{PKH}$ in improving the welfare of poor families with the perspective Islamic economics. This research is a field research that uses a qualitative descriptive approach. Sampling techniques are purposive sampling and snowball sampling. Primary data were obtained from Palembang City Social Service, Palembang City PKH Coordinator, Palembang Ilir Barat Dua Sub-District Assistant, and PKH Participants selected based on certain conditions. The results of study conclude that the implementation of PKH has been running effectively in Palembang City and in accordance with the objectives of the program. PKH has also had a positive impact on improving the economic welfare of poor families in the city of Palembang, but this welfare was not accompanied at the level of awareness in carrying out religious activities. Mean while Islamic Economics to measure the level of family welfare must consider the indicator of Religion.
\end{abstract}

Keywords: Social safety net, keluarga harapan, Islamic welfare

\begin{abstract}
Abstrak
Penelitian ini bertujuan untuk menganalisa efektivitas pelaksanaan PKH dalam meningkatkan kesejahteraan keluarga miskin di Kota Palembang dalam perspektif Ekonomi Islam. Penelitian ini merupakan penelitian lapangan (field research) yang menggunakan pendekatan Deskriptif kualitatif Teknik sampling dalam penelitian ini yaitu purposive sampling dan snowball sampling, Dengan mengumpulkan data melalui wawancara dan dokumentasi. Data primer di peroleh dari Dinas sosial kota Palembang, Koordinator PKH Kota Palembang, Pendamping Kecamatam Ilir Barat Dua Palembang, serta Peserta PKH yang dipilih berdasarkan syarat-syarat tertentu. Hasil penelitian ini menyimpulkan bahwa Pelaksanaan PKH telah berjalan dengan efektif sesuai dengan tujuan. PKH juga telah memberikan dampak positif terhadap peningkatan kesejahteraan ekonomi keluarga miskin di Kota Palembang khususnya kecamatan Ilir Barat Dua Palembang, Namun kesejahteraan tersebut tidak diiringi pada tingkat kesadaran dalam menjalankan aktivitas ibadah. Padahal dalam Ekonomi Islam untuk mengukur tingkat kesejahteraan keluarga harus mempertimbangkan indikator Religion.
\end{abstract}

Kata Kunci :Social safety net, Keluarga Harapan, Kesejahteraan Islam 


\section{Social Safety Net Pada Program Keluarga Harapan Dalam Meningkatkan Kesejahteraan Keluarga Miskin Di Kota Palembang}

M. Robby Kaharudin

\section{PENDAHULUAN}

Persoalan kemiskinan merupakan salah satu permasalahan pokok yang dihadapi bangsa Indonesia sejak dahulu hingga sekarang. Berbagai perencanaan, kebijakan serta program pembangunan yang telah dan akan dilaksanakan pada intinya adalah mengurangi jumlah penduduk miskin. Upaya pengentasan dan pengurangan kemiskinan harus dilakukan secara komperhensif, mencakup seluruh aspek kehidupan dan dilaksanakan secara terpadu. Menurut Soegijoko Seperti dikutip dari Frederic $W$. Nalle, menyatakan bawah Kemiskinan terjadi karena kemampuan masyarakat pelaku ekonomi tidak sama, sehingga terdapat masyarakat yang tidak dapat ikut serta dalam proses pembangunan atau menikmati hasil pembangunan(Frederic W. Nalle, Emilia K. Kiha: 2018).

Al-Qardhawi menjelaskan bahwa dalam pandangan Islam tidak dapat dibenarkan seseorang yang hidup di tengah masyarakat Islam -sekalipun Ahl alDzimma (warga negara non-muslim). Menderita lapar, tidak berpakaian, menggelandang (tidak bertempat tinggal). Dengan kata lain ajaran Islam menyatakan perang terhadap kemiskinan dan berusaha keras untuk membendungnya serta mengawasi kemungkinan yang dapat menimbulkannya (Yusuf al-Qardhawi: 2002).Islam, sebagai agama rahmatan lil'alamin mempunyai tanggungjawab besar untuk merespon masalah kemiskinan.Sebagai agama yang sempurna, Islam memiliki perhatian yang besar terhadap problem kemiskinan. Dalam konteks Negara Indonesia, Konstisusi negara juga menyatakan bahwa masyarakat miskin menjadi tanggung jawab negara, seperti yang termaktub secara eksplisit melalui UUD 1945 pasal 34 yang berisi "Fakir miskin dan anak-anak terlantar dipelihara oleh negara."

Pelaksanaan penanggulanan kemiskinan telah dilakukan pemerintah Indonesia sejak tahun 1998.Awalnya dilakukan untuk menyelesaikan masalah sosial akibat dari dampak krisis moneter yang melanda Indonesia.Tahun 1998 pemerintah Indonesia membuat sebuah program jaring pengaman sosial atau dikenal dengan Social Safety Net. Menurut Sumodiningrat, kebijakan program Social Safety Net ini bertujuan sebagai upaya penyelamatan (rescue) dan pemulihan (recovery) Ekonomi yang melanda masyarakat di Indonesia (Sumodiningrat, gunawan : 1999). Social Safety Net diciptakan untuk menjaga agar masyarakat tidak jatuh ke bawah tingkat kehidupan minimum yang dianggap layak oleh masyarakat tersebut.Seiring berjalannya waktu pemerintah 
Indonesia memperluas kebijakan Social Safety Net dengan program perlindungan sosial bagi penduduk miskin di indonesia. Tahun 2007 pemerintah pusat masa pemerintahan Susilo Bambang Yudhoyono mengeluarkan program penanggulangan kemiskinan yang bernama Program Keluarga Harapan (PKH) program ini merupakan duplikasi dari program pembrantasan kemiskinan yang dikenal didunia internasional yaitu Conditional cash transfer yang menggunakan sistim pendekatan Income support schemes(ISS) atau skema tunjangan pendapatan yang diberikan kepada rumah tangga miskin di Indonesia (Edi suharto: 2015). Kebijakan Program Keluarga Harapan (PKH) diatur melalui Undang Undang Republik Indonesia No. 40 Tahun 2004 tentang Jaminan Sosial yang ditindaklanjuti dengan Peraturan Presiden Nomor 15 Tahun 2010 tentang percepatan penangulangan kemiskinan. Program ini dilatar belakangi oleh adanya permasalahan utama pembangunan yaitu masih besarnya jumlah penduduk miskin serta rendahnya kualitas sumber daya manusia.

Pada tahun 2018 Pemerintah pusat melalui Kementerian sosial Republik Indonesia menambah jumlah penerima Program keluarga harapan (PKH) sebanyak 10.000.232 rumah tangga miskin dengan alokasi anggaran sebesar Rp. 17,5 Triliun (Edi Suharto: 2015). Di Palembang tahun 2020 jumlah penerima bantuan Program keluarga harapan (PKH) sebanyak 51.938 Keluarga miskin yang tersebar sebanyak 18 kecamatan di seluruh kota Palembang (Daryono:2020).Peserta PKH adalah rumah tangga sangat miskin (RTSM) atau keluarga sangat miskin (KSM) yang sesuai dengan kriteria BPS dan memenuhi beberapa kriteria program (Direktorat Jaminan sosial : 2013).

Penggunaan dana bantuan PKH diharapkan pemerintah untuk digunakan dalam membeli kebutuhan dasar yang menunjang pendidikan, kesehatan dan perbaikan ekonomi keluarga. Namun pada kenyataannya berdasarkan temuan Pusat Kajian Jaminan Sosial (PKJS) Universitas Indonesia, penerima bantuan PKH tersebut mayoritas adalah seorang perokok aktif. Sehingga, ditemukan beberapa keluarga penerima manfaat (KPM) yang membelanjakan bantuan untuk membeli rokok. Dengan temuan ini, ada potensi dana PKH yang diambilkan dari anggaran pendapatan belanja negara (APBN) justru mengalir untuk pembelian rokok.Padahal seharunya dana bantuan PKH wajib dimanfaatkan dengan tepat agar sesuai dengan harapan Program. Seperti halnya pidato yang disampaikan oleh Presiden Republik Indonesia Bapak Joko widodo 


\section{Social Safety Net Pada Program Keluarga Harapan Dalam Meningkatkan Kesejahteraan Keluarga Miskin Di Kota Palembang}

M. Robby Kaharudin

yang menerangkan bahwa penggunaan dana $\mathrm{PKH}$ harus digunakan dengan tepat. Misalnya untuk beli kebutuhan primer seperti telur, ikan, buku sekolah, seragam anak, sepatu anak yang bisa menunjang pendidikan dan kesehatan keluarga.

Program Keluarga Harapan memiliki dua fungsi yaitu untuk jangka pendek dengan membantu meringankan beban pengeluaran keluarga miskin dan jangka panjang, untuk memutus mata rantai kemiskinan antar generasi dengan meningkatkan sumber daya manusia melalui kesehatan dan pendidikan (Pedoman Umum PKH : 2019). Seiring dengan berjalannya Program Keluarga Harapan (PKH) di Kota Palembang, ternyata tidak memberikan dampak signifikan terhadap penurunan angka kemiskinan yang ada di kota Palembang. Dari data Badan Pusat Statistik Provinsi Sumatera Selatan per bulan maret tahun 2018 jumlah penduduk miskin di kota Palembang masih mencapai 179,32 ribu orang (BPS: 2018).

Tabel 1.

Jumlah Penduduk miskin Kota Palembang

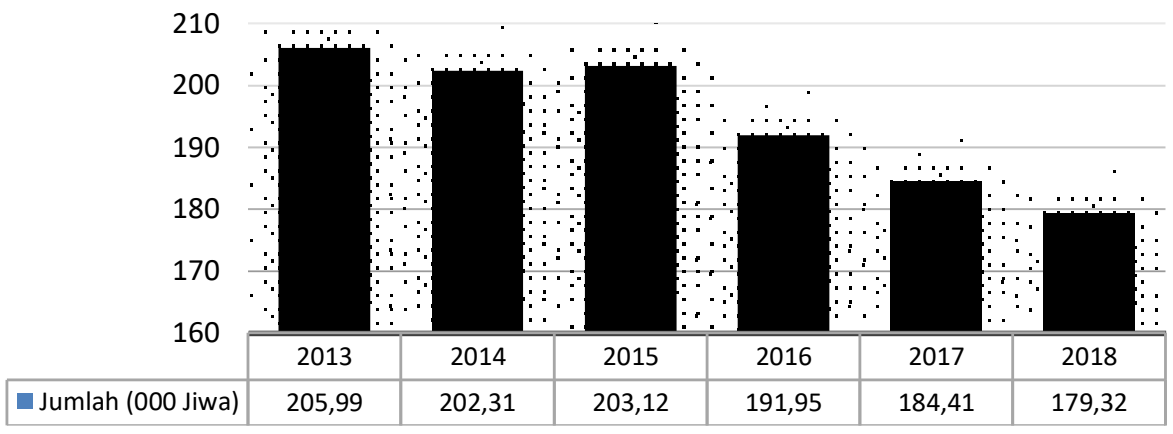

Sumber:BPS 2018

Tabel 2.

Persentase Kemiskinan kota Palembang, Sumsel dan Nasional

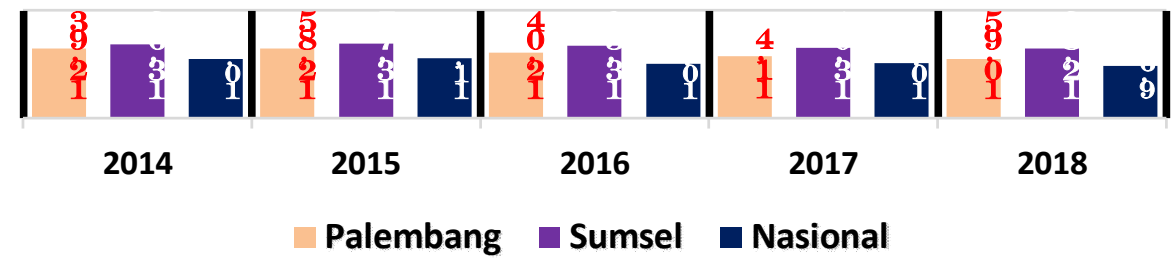

Sumber: BPS 2018 
Pada skala nasional kota Palembang juga termasuk kota yang memiliki jumlah penduduk miskin yang cukup besar, melampaui dari nilai rata-rata masyarakat miskin secara nasional sebesar 9,66\%. Dari tabel diatas menunjukkan bahwa persoalan kemiskinan dikota Palembang merupakan persoalan besar yang perlu diselesaikan dengan cepat agar terciptanya kesejahteraan yang merata pada penduduk kota Palembang. Sesuai dengan amanat konstitusi, yaitu memberikan perlindungan dan menjamin kesejahteraan bagi seluruh rakyat Indonesia.

\section{TINJAUAN TEORITIK}

\section{Kesejahteraan Islam}

Pandangan ekonomi Islam tentang kesejahteraan didasarkan atas keseluruhan ajaran Islam tentang kehidupan ini. Konsep ini sangat berbeda dengan konsep kesejahteraan dalam ekonomi konvensional, sebab ia adalah konsep yang holistik. Secara singkat kesejahteraan yang diinginkan oleh ajaran Islam adalah: a). Kesejahteraan holistik dan seimbang, yaitu mencakup dimensi material maupun spiritual serta mencakup individu maupun sosial b). Kesejahteraan di dunia maupun di akhirat, sebab manusia tidak hanya hidup di alam dunia saja tetapi juga di alam akhirat.Jika kondisi ideal ini tidak dapat dicapai maka kesejahteraan di akherat tentu lebih diutamakan.Istilah yang banyak digunakan untuk menggambarkan suatu keadaan hidup yang sejahtera secara material-spiritual pada kehidupan di dunia dan akhirat dalam bingkai ajaran Islam adalah Fallah. Dalam pengertian sederhana, Fallah adalah kemuliaan dan kemenangan dalam hidup (M. B. Hendrie Anto:2003).

Komitmen Islam yang mendalam terhadap persaudaraan dan keadilan menyebabkan konsep kesejahteraan (Fallah) bagi semua umat manusia sebagai tujuan pokok Islam.Kesejahteraan ini meliputi kepuasan fisik sebab kedamaian mental dan kebahagiaan hanya dapat dicapai melalui realisasi yang seimbang antara kebutuhan materi dan rohani dari personalitas manusia.Untuk kehidupan dunia, Fallah mencakup tiga pengertian, yaitu kelangsungan hidup, kebebasan berkeinginan (free-will), serta kekuatan dan kehormatan. Sedangkan untuk kehidupan akhirat, Fallah mencakup pengertian kelangsungan hidup yang abadi, kesejahteraan abadi, kemuliaan abadi, dan pengetahuan abadi (bebas dari segala kebodohan) (P3EI UII: 2008). Fallah, kehidupan yang mulia dan sejahtera di 


\section{Social Safety Net Pada Program Keluarga Harapan Dalam Meningkatkan Kesejahteraan Keluarga Miskin Di Kota Palembang}

M. Robby Kaharudin

dunia dan akhirat dapat terwujud apabila terpenuhi kebutuhan-kebutuhan hidup manusia secara seimbang. Tercukupinya kebutuhan masyarakat akan memberikan dampak yang disebut dengan mashlahah.Mashlahah adalah segala bentuk keadaan, baik material maupun non material, yang mampu meningkatkan kedudukan manusia sebagai makhluk yang paling mulia.

Menurut Ikhwan Abidin Basri, Kesejahteraan ekonomi syariah bertujuan mencapai kesejahteraan manusia secara menyeluruh, yaitu kesejahteraan material, kesejahteraan spiritual dan moral. Konsep ekonomi kesejahteraan syariah bukan saja berdasarkan manifestasi nilai ekonomi, tetapi juga nilai moral dan spiritual, nilai sosial dan nilai politik Islami(Ikhwan Abidin Basri: 2016). Secara terperinci, tujuan ekonomi Islam dapat dijelaskan sebagai berikut: 1). Kesejahteraan ekonomi adalah tujuan ekonomi yang terpenting. Kesejahteraan ini mencakup kesejahteraan individu, masyarakat dan negara. 2). Tercukupinya kebutuhan dasar manusia, meliputi makan, minum, pakaian, tempat tinggal, kesehatan, pendidikan, keamanan serta system negara yang menjamin terlaksananya kecukupan kebutuhan dasar secara adil dibidang ekonomi, 3). Penggunaan sumberdaya secara optimal, efisien, efektif, hemat dan tidak mubazir, 4). Distribusi harta, kekayaan, pendapatan dan hasil pembangunan secara adil dan merata, 5). Menjamin kebebasan individu 6). Kesamaan hak dan peluang, 7).Kerjasama dan keadilan. Dalam Mu'jam musthalahatu al-ulum alIjtima'iyah, defenisi kesejahteraan adalah kondisi yang menghendaki terpenuhinya kebutuhan dasar bagi individu atau kelompok baik berupa kebutuhan pangan, pendidikan, kesehatan, sedangkan lawan dari kesejahteraan adalah kesedihan (bencana) kehidupan (Warkum sumito: 2010).

Begitupun Menurut Pendapat Al Ghazalimendefinisikan aspek kegiatan ekonomi dari fungsi kesejahteraan sosialnya dalam kerangka sebuah hierarki utilitas individu dan sosial yang tripastite, yakni kebutuhan (dharuriyah), kesenangan atau kenyamanan (hajiyah), dan kemewahan (tahsiniyah). Kunci pemeliharaan dari kelima tujuan dasar ini terletak pada penyediaan tingkat pertama (Boedi Abdullah:201). Dharuriyah adalah kemaslahatan esensial bagi kehidupan manusia dan karena itu wajib ada sebagai syarat mutlak terwujudnya kehidupan itu sendiri, baik ukhrawi maupun duniawi. Dengan kata lain, jika dharuriyah itu tidak terwujud, niscaya kehidupan manusia akan punah sama sekali. Di sisi lain, hajiyah adalah segala hal yang menjadi kebutuhan primer 
manusia agar hidup bahagia dan sejahtera dunia dan akhirat, dan terhindar dari berbagai kesengsaraan. Jika kebutuhan ini tidak dipenuhi, maka kehidupan manusia akan mengalami kesulitan (masyaqah).Tingkatan terakhir adalah tahsiniyyah, yakni kebutuhan hidup komplementer-sekunder untuk menyempurnakan kesejahteraan hidup manusia. Jika aspek tahsiniyyah tidak terpenuhi, maka kemaslahatan hidup manusia kurang sempurna dan kurang nikmat meski tidak menyebabkan kesengsaraan(Hamka Haq, Al-Syatibi:2007).

Kesejahteraan menurut Al-Ghazali adalah tercapainya kemaslahatan.Kemaslahatan sendiri merupakan terpeliharanya tujuan syara' (Maqashid Syariah).Manusia tidak dapat merasakan kebahagiaan dan kedamaian batin melainkan setelah tercapainya kesejahteraan yang sebenarnya dari seluruh ummat manusia di dunia melalui pemenuhan kebutuhan-kebutuhan ruhani dan materi. Untuk mencapai tujuan syara' agar dapat terealisasi kemaslahatan, beliau menjabarkan tentang sumber-sumber kesejahteraan yakni: terpeliharanya keimanan (al-din), jiwa (al-nafs), akal (al-zaql), keturunan (alnasl), dan kekayaan (al-mal).Harta merupakan sarana yang penting dalam menciptakan kesejahteraan ummat.Dalam hal tertentu harta juga dapat membuat bencana dan malapetaka bagi manusia.Al-Ghazali urutkan prioritasnya dalam urutan kelima maqashid al-syariah.Keimanan dan harta benda sangat diperlukan dalam kebahagiaan manusia.Namun imanlah yang membantu menyuntikkan suatu disiplin dan makna, sehingga dapat menghantarkan harta sesuai tujuan syariah. Keimanan ditempatkan di urutan pertama karena memberikan cara pandang dunia yang cenderung mempengaruhi kehidupan yaitu perilaku, gaya hidup, selera, dan preferensi manusia, dan sikap-sikap terhadap manusia, sumber daya, dan lingkungan. Ini sangat mempengaruhi sifat, kuantitas, dan kualitas kebutuhan materi, maupun kebutuhan psikologis dan cara pemuasannya. Kekayaan ditempatkan di belakang, bukan karena kurang penting, tetapi lebih karena tidak mesti membantu mewujudkan kesejahteraan dari semua manusia (Umer Chapra: 2001). Syariat menghendaki kehidupan yang layak dan sejahtera. Maksudnya, syariat dapat terlaksana dengan baik jika manusia mempunyai kehidupan yang sejahtera dan tidak menghendaki manusia dalam hidupnya mengalami penderitaan dan kepunahan lantaran ketiadaan harta. Karena itu, pemeliharaan harta menjadi salah satu tujuan syariat, dalam arti mendorong manusia untuk memperolehnya dan mengatur pemanfaatannya 


\section{Social Safety Net Pada Program Keluarga Harapan Dalam Meningkatkan Kesejahteraan Keluarga Miskin Di Kota Palembang}

M. Robby Kaharudin

(Hamka Haq:2007). Sementara tiga tujuan lainnya (jiwa, akal, dan keturunan) berhubungan dengan manusia itu sendiri, yang kesejahteraannya merupakan tujuan utama syariah. Ini mencakup kebutuhan fisik maupun moral, psikologi dan akal untuk generasi sekarang dan yang akan datang. Berikut tabel Indikator Kesejahteraan dalam Islam.

Tabel 3 .

Indikator Kesejahteraan Dalam Islam

\begin{tabular}{|c|c|}
\hline Aspek & Uraian \\
\hline $\begin{array}{l}\text { 1). (Religion) Terpenuhinya } \\
\text { ketentraman batin dengan kegiatan } \\
\text { ibadah dan kedekatan terhadap } \\
\text { Tuhannya secara ikhlas. }\end{array}$ & $\begin{array}{l}\text { a). Melaksanakan ibadah, sesuai dengan } \\
\text { ajaran agama/kepercayaan yang dianut } \\
\text { oleh masing masing keluarga/anggota } \\
\text { keluarga; } \\
\text { b). Mendengarkan ceramah agama atau } \\
\text { ikut dalam kegiatan mengaji. }\end{array}$ \\
\hline $\begin{array}{l}\text { 2). (Physical self) Terpenuhi } \\
\text { nyakebutuhan hidup pokok bagi } \\
\text { keluarga penerima bantuan } \mathrm{PKH} \text {. }\end{array}$ & $\begin{array}{l}\text { a). Terpenuhinya kebutuhan makan nasi } \\
\text { minimal sekali dalam dua hari. } \\
\text { b). Paling kurang sekali seminggu seluruh } \\
\text { anggota keluarga makan } \\
\text { daging/ikan/telur. } \\
\text { c). Memiliki tempat tinggal yang layak } \\
\text { (beratap dan dinding). }\end{array}$ \\
\hline $\begin{array}{l}\text { 3). (knowledge) Hilangnya rasa } \\
\text { takut, yang } \\
\text { representasi dari terciptanya rasa } \\
\text { aman, nyaman, dan damai. }\end{array}$ & $\begin{array}{l}\text { a). Terjaminnya tingkat keamanan di } \\
\text { tempat tinggal serta terhindar dari aksi } \\
\text { kriminal dan } \\
\text { b). Mendapatkan kemudahan akses } \\
\text { fasilitas } \\
\text { c). Mendapatkan akses layanan kesehatan } \\
\text { dengan mudah. }\end{array}$ \\
\hline
\end{tabular}

\section{Social Safety Net}

Paket bantuan sosial bagi masyarakat rentan krisis dalam kerangka jaring pengaman sosial ditempuh pertama kali oleh Presiden Roosevelt pada tahun 1930-an di Amerika Serikat. Depresi ekonomi yang melanda Amerika Serikat disertai badai salju yang parah mengakibatkan lumpuhnya sebagian besar 
kegiatan ekonomi riil negara itu.Angka pengangguran meningkat tinggi, serta terjadi kontraksi ekonomi yang disertai dengan melambungnya harga kebutuhan pokok.Menurunnya produktivitas berbagai sektor perekonomian ini mengakibatkan daya beli masyarakat menurun yang mengakibatkan ketidakmampuan masyarakat memenuhi kebutuhan pokok.Akibatnya kualitas hidup sebagian besar masyarakat menurun drastis.Kondisi ini kemudian segera diatasi melalui langkah jangka pendek (crash program) dengan tujuan memulihkan kegiatan ekonomi dan menanggulangi dampak sosial (Gunawan Sumodiningrat: 1999).

Konsep Social Safety Net diperkenalkan juga oleh para ekonom kapitalis pada saat proses peralihan ekonomi di negara-negara Eropa timur pada tahun 1990-an. Saat itu terjadi transisi ekonomi dari sistem ekonomi sosialis ke sistem ekonomi pasar. Proses transisi ekonomi sosialis mendapat jatah pangan gratis dari pemerintah menjadi tidak lagi mendapat jatah pangan gratis (Mubyarto: 1998). Bank dunia menyebutkan bahwa program social safety net ditujukan untuk melindungi kelompok orang atau keluarga yang mengalami kondisi penurunan kapasitas secara kronis sehingga kehilangan pekerjaan dan pendapatan tetap (chronic poverty) dan kelompok orang atau keluarga yang mengalami penurunan kapasitas dari garis merjinal kemiskinan sehingga tidak mampu lagi memenuhi kebutuhan untuk bertahan hidup (transient powerty), perlindungan sosial diperlukan guna menggerakkan produktifitas mereka melalui pemberian kesempatan kerja dan bantuan sosial dasar terutama kesehatan dan pendidikan. Setiap orang dan keluarga yang menderita akibat krisis menjadi prioritas kelompok sasaran penerima bantuan program social safety net.Pengalaman Bank dunia dibeberapa negara yang pernah dilanda krisis ekonomi menunjukkan bahwa peningkatan kapasitas kelompok masyarakat rentan krisis (capacity building) termasuk kelompok masyarakat miskin dapat dilakukan melalui upaya pemberdayaan masyarakat rentan (empowerment). Sasaran kegiatan pemberdayaan masyarakat dilakukan melalui berbagai komponen program yang memberikan peluang bagi kelompok masyarakat rentan krisis untuk mendapatkan akses ke sumberdaya produksi (Subbarao: 1997).Social Safety Net adalah konsep yang dirancang untuk membantu rakyat miskin yang terkena dampak akibat krisis ekonomi dan dilaksanakan melalui tahapan penyelamatan dan pemulihan menuju pada kondisi yang 


\section{Social Safety Net Pada Program Keluarga Harapan Dalam Meningkatkan Kesejahteraan Keluarga Miskin Di Kota Palembang}

M. Robby Kaharudin

normal.Menurut Sumodiningrat, Kebijakan Social Safety Net ini bertujuan sebagai upaya penyelamatan (rescue) dan pemulihan (recovery) Ekonomi yang melanda masyarakat di Indonesia (Sumodiningrat: 1999).

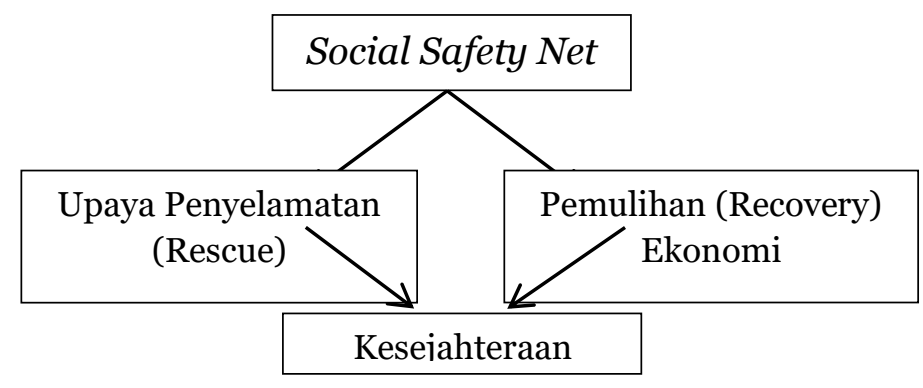

\section{Gambar 1 \\ Konsep Social Safety Net}

Di Indonesia Social safety net salah satunya di implementasikan pada Program Keluarga Harapan (PKH). PKH adalah program pemberian uang tunai kepada Rumah Tangga Sangat Miskin (RTSM) berdasarkan persyaratan dan ketentuan yang telah ditetapkan dengan melaksanakan kewajibannya. Program semacam ini secara internasional dikenal sebagai program conditional cash transfers (CCT) atau program Bantuan Tunai Bersyarat. Persyaratan tersebut dapat berupa kehadiran di fasilitas pendidikan (bagi anak usia sekolah), ataupun kehadiran di fasilitas kesehatan (bagi anak balita, atau bagi ibu hamil). Tujuan PKH adalah untuk mengurangi angka dan memutus rantai kemiskinan, meningkatkan kualitas sumber daya manusia, serta mengubah perilaku yang kurang mendukung peningkatan kesejahteraan dari kelompok paling miskin. Tujuan ini berkaitan langsung dengan upaya mempercepat pencapaian target Millennium Development Goals (MDGs). Secara khusus, tujuan PKH adalah: a). untuk meningkatkan taraf hidup Keluarga Penerima Manfaat melalui akses layanan pendidikan, kesehatan, dan kesejahteraan sosial; b). mengurangi beban pengeluaran dan meningkatkan pendapatan keluarga miskin dan rentan; c). Menciptakan perubahan perilaku dan kemandirian Keluarga Penerima Manfaat dalam mengakses layanan kesehatan dan pendidikan serta kesejahteraan sosial; d). Mengurangi kemiskinan dan kesenjangan; dan e). Mengenalkan manfaat produk dan jasa keuangan formal kepada Keluarga Penerima Manfaat. 


\section{Teori Efektivitas}

Efektivitas adalah pencapaian sasaran dari upaya bersama (Pasolong, Harbani: 2014). Konsep efektivitas sebagai suatu ukuran yang memberikan gambaran seberapa jauh target dapat tercapai(Sedarmayanti:2009). Sedangkan menurut Subkhi dan Jauhar efektivitas adalah hubungan antara output dan tujuan (Nurul Najidah: 2017).Berdasarkan definisi efektivitas diatas, dapat disimpulkan bahwa efektivitas merupakan kemampuan kerja yang dilakukan oleh seseorang atau organisasi untuk mencapai tujuan yang telah ditentukan sebelumnya.Tingkat efektivitas dapat diukur dengan membandingkan antara rencana yang telah ditentukan dengan hasil nyata yang telah diwujudkan. Usaha atau hasil pekerjaan dan tindakan dilakukan haruslah tepat, jika tidak tepat menyebabkan tujuan tidak tercapai atau dengan kata lain dikatakan tidak efektif.

Efektivitas program merupakan suatu cara untuk mengukur sejauh mana suatu program berjalan, guna mencapai tujuan yang telah diterapkan sebelumnya. Efektivitas program merupakan kegiatan yang pelaksanannnya menampakkan ketepatan antara harapan yang kita inginkan dengan hasil yang di capai, dimana ditunjukkan dengan ketepatan harapan, impelementasi, dan hasil yang dicapai (Makmur: 2011). Berdasarkan pernyataan diatas, dapat disimpulkan bahwa efektivitas program adalah tingkat perwujudan dari perumusan tujuan yang ditentukan oleh suatu kelompok, dimana didalamnya terdapat tugas-tugas pokok. Menurut Makmur, efektivitas dapat dilihat dari beberapa segi kriteria, sebagai berikut (Makmur:2011): 1).Ketepatan perhitungan biaya, 2). Ketepatan berpikir, 3).Ketepatan tujuan, 4).Ketepatan sasaran.

\section{METODE PENELITIAN}

Jenis penelitian ini adalah penelitian kualitatif.Fenomena yang diselidiki dalam penelitian ini adalah fenomena peningkatan kesejahteraan keluarga miskin melalui Program Keluarga Harapan (PKH), Penelitian ini menggunakan landasan teori sebagai pemandu agar fokus penelitian sesuai dengan fakta di lapangan.Sifat penelitian ini adalah deskriptif.Penelitian ini termasuk ke dalam penelitian lapangan (field research) karena peneliti terlibat langsung dalam penelitian dengan mengumpulkan data dan informasi yang diperoleh langsung dari informan.Jadi, melalui penelitian deskriptif ini agar peneliti mampu mendiskripsikan penerapan social safety net pada Program Keluarga Harapan 


\section{Social Safety Net Pada Program Keluarga Harapan Dalam Meningkatkan Kesejahteraan Keluarga Miskin Di Kota Palembang}

M. Robby Kaharudin

(PKH) di kota Palembang serta efektifitas pelaksanaan PKH terhadap peningkatan kesejahteraan keluarga miskin di kota Palembang.

Teknik sampling dalam penelitian ini menggunakan teknik purposive sampling dan snowball sampling.Dalam penelitian ini yang menjadi informan yaitu; 1).Kepala Dinas Sosial Kota Palembang, 2).Koordinator PKH Kota Palembang, 3).Pendamping PKH kecamatan Ilir barat Dua 4).Keluarga penerima manfaat (KPM) yang memenuhi kriteria tertentu. Adapun kriteria yang dijadikan sebagai sampel penelitian yaitu Keluarga penerima manfaat (KPM) di Kecamatan Ilir Barat Dua Palembang yang telah menerima bantuan minimal selama delapan tahun atau sejak tahun 2011 lalu dipilih lagi yang memiliki komponen pendidikan dan kesehatan.

Lokasi penelitian ini di unit pelaksana Program keluarga Harapan kota Palembang. Fokus Informan yang dijadikan sampel adalah wilayah kecmatan Ilir Barat Dua karena wilayah ini mampu merepresentasikan dari hasil penelitian.Data dalam penelitian ini adalah data primer dan sekunder.Teknik pengumpulan data dalam penelitian ini dilakukan melalui metode wawancara dan dokumentasi.Teknik Pengolahan dan Analisa Data menggunakan model analisis interaktif miles dan huberman yaitu penggumpulan data, reduksi data, penyajian data dan tahap terakhir penarikan kesimpulan.

\section{HASIL DAN PEMBAHASAN PENELITIAN}

\section{Ketepatan Sasaran}

Ketepatan sasaran merupakan hal penting yang menentukan berhasil atau tidaknya program.Program dapat dikatakan efektif, apabila sesuai dengan sasaran yang telah ditetapkan, berdasarkan aturan yang telah disepakati. Sasaran yang tepat, baik yang ditetapkan secara individu maupun secara organisasi sangat menentukan suatu keberhasilan (Makmur: 2011). Sasaran PKH merupakan keluarga miskin dan rentan serta terdaftar dalam basis data terpadu (BTD) atau data terpadu kesejahteraan sosial (DTKS) program penanganan fakir miski.Selanjutnya memiliki komponen kesehatan, pendidikan, dan/atau kesejahteran sosial. Menurut hasil wawancara ke kepala jaminan sosial dan keluarga dinas sosial kota Palembang, data yang diambil dalam menentukan sasaran program keluarga harapan (PKH) berusmber dari BDT (Basis data terpadu) yang merupakan data miskin yang diperoleh dari hasil sensus 
penduduk. Lalu penerima PKH memiliki tiga komponen yaitu komponen kesehatan, pendidikan dan kesejahteraan sosial.

1. Kriteria Komponen Kesehatan, Sasaran kriteria kesehatan Program Keluarga Harapan $(\mathrm{PKH})$ di kota Palembang dalam komponen kesehatan sudah sesuai kriteria sasaran yang telah ditetapkan. Kriteria komponen kesehatan di Kota Palembang telah mencakup keluarga miskin dan rentan yang telah terdaftar di Basis Data Terpadu (BDT) yang memiliki komponen ibu hamil atau menyusui atau anak berusia o (nol) sampai dengan 6 (enam) tahun. Ketepatan sasaran kriteria komponen kesehatan di Kota Palembang, dapat terjadi karena adanya beberapa cara yang dilakukan pendamping $\mathrm{PKH}$ yaitu melakukan verifikasi antara Basis Data Terpadu (BDT) dengan keluarga penerima manfaat komponen kesehatan di Kota Palembang, yang dilakukan melalui verifikasi rutin maupun home visit oleh pendamping $\mathrm{PKH}$ setiap tiga bulan kepada para KPM di Kota Palembang dan terjalinnya koordinasi baik dengan pihak berwenang mulai dari kelurahan, RW hingga RT setempat guna memudahkan proses evaluasi.

2. Kriteria Komponen Pendidikan, dalam sasaran kriteria komponen pendidikan di Kota Palembang telah sesuai sasaran, yaitu mencakup warga miskin dan rentan miskin yang memiliki anak SD, SMP dan SMA yang telah terdaftar dalam BDT. Proses pengawasan dalam memastikan kriteria pendidikan ini dilakukan dengan cara mengkonfirmasi langsung kesekolah siswa penerima PKH yang bersangkutan . Dalam melakukan pemutahiran data pendamping PKH setiap tiga bulan melakukan kunjungan ke sekolah untuk melakukan proses control terhadap kehadiran siswa.

3. Kriteria Komponen Kesejahteraan Sosial, sasaran kriteria komponen kesejahteraan sosial Program Keluarga Harapan (PKH) di Kota Palembang, dalam komponen lanjut usia belum mencakup semua lansia sesuai sasaran, sedangkan pada penyandang disabilitas berat telah sesuai sasaran yaitu telah mengcover semua penyandang disabilitas berat dari keluarga miskin dan rentan miskin. Penyebab belum tercakup semua lansia sesuai kriteria dalam komponen kesejahteraan sosial ialah belum terdaftarnya lansia dalam Basis Data Terpadu dan tidak lagi sesuai sasaran. Proses pendaftaran BDT yang agak sulit dilakukan menjadi faktor pemnghambat tercakupnya semua lansia di PKH. 


\section{Social Safety Net Pada Program Keluarga Harapan Dalam Meningkatkan Kesejahteraan Keluarga Miskin Di Kota Palembang}

M. Robby Kaharudin

\section{Ketepatan Tujuan}

1. Untuk meningkatkan taraf hidup Keluarga Penerima Manfaat melalui akses layanan pendidikan, kesehatan, dan kesejahteraan sosial;

Peningkatan taraf hidup keluarga penerima manfaat melalui akses layanan pendidikan, kesehatan dan kesejahteraan sosial merupakan tujuan yang sangat penting dari Program PKH.Oleh karenanya setiap peserta $\mathrm{PKH}$ diwajibkan untuk menyekolahkan anaknya di fasilitas pendidikan (komponen pendidikan) serta wajib menghadiri fasilitas kesehatan (komponen kesehatan) untuk menjaga kesehatan keluarga.Dalam aturannya peserta diwajibkan memenuhi komitmen kehadiran di fasilitas kesehatan minimal satukali setiap bulannya, untuk komponen pendidikan wajib hadir disekolah minimal $85 \%$ kehadiran setiap bulannya baik SD/SMP/SMA.Untuk Lansia dan disabilitas diwajibkan ikut serta dalam Homecare dan Homevisit. Jika peserta PKH tidak komitmen menjalankan kewajibannya maka akan dikenakan sanksi penangguhan bantuan. Kewajiban tersebut dimaksudkan agar peserta $\mathrm{PKH}$ benar-benar memerhatikan pendidikan bagi keluarganya. Peningkatan kualittas pendidikan akan berdampak terhadap terputusnya mata rantai kemiskian pada keluarga tersebut. Pendidikanlah yang akan membawa keluarga miskin keluar dari kemiskinan. Sementara perhatian terhadap kesehatan akan berdampak pada peningkatan gizi keluarga yang berpengaruh pada kekuatan tubuh. Berikut adalah distribusi jawaban informan berdasarkan dampak penggunaan dana PKH terhadap pendidikan anak.

Berdasarkan hasil penelitian, ditemukan bahwa $\mathrm{PKH}$ memberikan dampak positif terhadap pendidikan anak para peserta $\mathrm{PKH}$. Dari 30 informan mayoritas menyatakan bahwa $\mathrm{PKH}$ ini memberikan dampak terhadap pendidikan anaknya sebanyak 18 Informan dengan persentase (60\%) dan 12 informan dengan (40\%) menyatakan berpengaruh. Selain itu, juga memberikan dampak dalam memenuhi kebutuhan makan keluarga, Sebanyak 15 informan dengan persentase (50\%) menyatakan sangat berpengaruh, 14 Informan (47\%) menyatakan berpengaruh dan 1 Informan (3\%) menyatakan kurang berpengaruh.

2. Mengurangi beban pengeluaran dan meningkatkan pendapatan keluarga miskin dan rentan; 
Program keluarga harapan (PKH) dinilai telah membantu keluarga miskin peserta $\mathrm{PKH}$ dalam mengurangi beban pengeluaran dan meningkatkan pendapatan keluarga.Program PKH memiliki skema bantuan tujangan pendapatan.Setiap peserta $\mathrm{PKH}$ menerima bantuan berupa uang tunai dengan jumlah masing-masing keluarga memiliki nominal yang berbeda berdasarkan komponen keluarga tersebut. Untuk komponen Ibu hamil, Anak usia dini, Lansia dan disabilitas menerima Rp 2.400.00o/tahun, Untuk keluarga yang memiliki anak SD 900.00o/ tahun, anak SMP 1.500.000/tahun, anak SMA 2.000.00o/tahun. Bantuan akan diberikan maksimal empat komponen dalam satu keluarga. Berdasarkan pernyataan informan bantuan tunai tersebut sangat dirasakan oleh peserta $\mathrm{PKH}$ dalam meringankan baban keluarga peserta $\mathrm{PKH}$.

3. Menciptakan perubahan perilaku dan kemandirian Keluarga Penerima Manfaat dalam mengakses layanan kesehatan dan pendidikan serta kesejahteraan sosial;

Perubahan perilaku peserta PKH juga merupakan tujuan dari program keluarga harapan.Perubahan perilaku kearah positif ini bertujuan untuk memberikan dampak terhadap kesehatan, pendidikan dan kesejahteraan sosial peserta PKH.Dalam membina peserta $\mathrm{PKH}$ agar mengalami perubahan prilaku sehari-harinya peserta $\mathrm{PKH}$ diwajibkan untuk mengikuti kegiatan rutin bulanan yang dampingi langsung oleh pendamping $\mathrm{PKH}$. Tenaga Pendamping sosial PKH di kota Palembang jumlahnya sebanyak 240 orang dan tersebar di 18 kecamatan se-kota Palembang. Pertemuan tersebut dilakukan secara kolektif dengan dibentuk kelompok.Pertemuan ini disebut dengan P2K2 (Pertemuan peningkatan kemampuan keluarga).Tujuannya untuk melakukan pembinaan, mengubah mindset sekaligus memberikan materi sesuai dengan modul yang telah diatur dalam pedoman PKH.Modul yang menjadi bahasan dari pertemuan tersebut berupa modul pendidikan, pengasuhan, kesehatan, ekonomi dan kesejahteraan sosial.Pertemuan P2K2 adalahi ruh dari program ini.Karena inilah yang membedakan PKH dengan program jaring pengaman sosial lainnya. Perubahan mindset keluarga miskin akan memberikan dorongan terhadap peserta $\mathrm{PKH}$ untuk meningkatkan kemampuan keluarganya agar bisa keluar dari keluarga miskin. Untuk memastikan adanya perubahan prilaku peserta $\mathrm{PKH}$ dalam 


\section{Social Safety Net Pada Program Keluarga Harapan Dalam Meningkatkan Kesejahteraan Keluarga Miskin Di Kota Palembang}

M. Robby Kaharudin

mengakses layanan pendidikan dan kesehatan pendamping PKH kota Palembang melakukan verifikasi komitmen kehadiran di fasilitas pendidikan dan fasilitas kesehatan peserta $\mathrm{PKH}$.

4. Mengurangi kemiskinan dan kesenjangan

Turunya angka kemiskinan dan kesejangan merupakan tujuan pokok program PKH. Dalam pelaksanaannya di kota Palembang selama kurun waktu lima tahun terakhir. Data BPS Kota Palembang menunjukkan bahwa terjadi penurunan angka kemiskinan di kota Palembang sejak tahun 20132018, tetapi penurunan angka kemiskinan tersebut cenderung bergerak lambat.

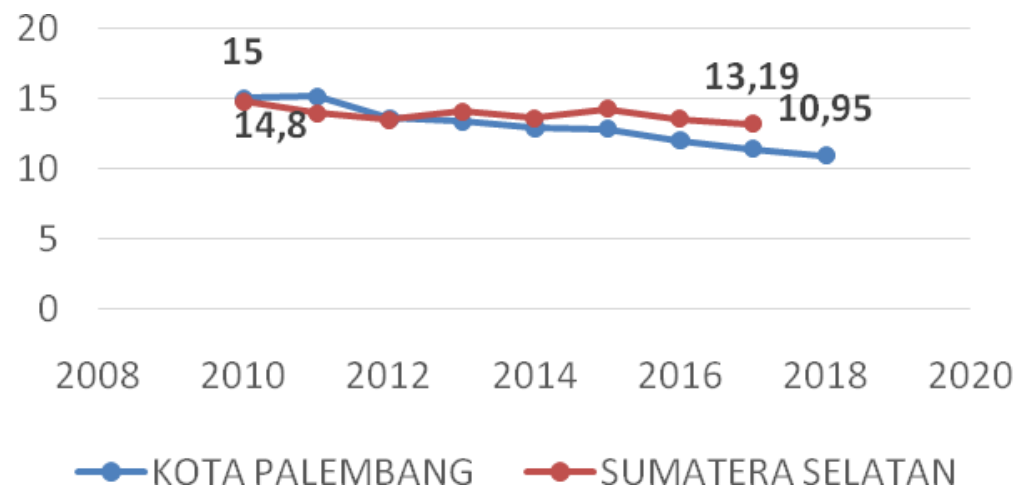

\section{Gambar 6}

\section{Statistik Kemiskinan}

Program keluarga harapan telah membantu pemerintah dalam menurunkan angka kemiskinan di kota Palembang, dari statistik kemiskinan BPS. Namun penurunan tersebut cenderung lambat. Ini terjadi karena beberapa pelaksanaan program PKH yang dinilai masih kurang maksimal. Salah satu contohnya saja ada beberapa data yang terdata di BDT yang kurang tepat sasaran dan upaya perbaikan itu sudah mulai Dinas Sosial kota Palembang lakukan dengan melakukan pemutahiran data BDT di tahun 2019 lalu.

5. Mengenalkan manfaat produk dan jasa keuangan formal kepada Keluarga Penerima Manfaat.

Salah satu tujuan PKH adalah untuk mengenalkan manfaat produk dan jasa keuangan formal kepada keluarga penerima manfaat.Salah satu jasa keuangan yang dimaksud ada pihak perbankan.Dalam pengenalan lembaga 
keuangan tersebut PKH menginisiasi penyaluran bantuan melalui Rekening dan ATM yang dimiliki setiap peserta PKH.Teknis penyaluran ini merupakan upaya pemerintah melakukan transparansi terhadap penyaluran bantuan sosial. Setiap peserta PKH akan diberikan buku tabungan dan ATM dari penyelenggara program. Di Palembang menggunakan Bank BRI sebagai lembaga penyalur bantuan dana PKH. Setiap jadwal pencairan, peserta $\mathrm{PKH}$ bisa secara langsung menarik saldo bantuannya di ATM terdekat.

\section{Ketepatan Biaya}

Ketepatan biaya merupakan faktor yang mempengaruhi efektivitas program. Makmur menjelaskan ketepatan biaya berkaitan dengan ketepatan pemanfaatan biaya dan tidak mengalami kekurangan juga tidak mengalami kelebihan jumlah pembiayaan sampai kegiatan dapat dilaksanakan dengan baik (Makmur:2011). Dari hasil wawancara ke informan mengenai jawaban terhadap penggunaan dana bantuan PKH dengan jumlah informan sebanyak tiga puluh peserta PKH ditemukan jawaban yang berpariatif. Mayoritas keluarga miskin peserta $\mathrm{PKH}$ dalam pengakuannya menggunakan dana $\mathrm{PKH}$ untuk keperluan pendidikan anak, diantaranya juga menggunakannya untuk membeli kebutuhan makan sehari-hari seperti beras dan lauk pauk, sebagian kecil lagi menggunakan nya untuk kebutuhan biaya listrik dan air, ada juga yang menggunakannya untuk modal usaha.

Dari hasil penelitian menerangkan bahwa penggunaan dana $\mathrm{PKH}$ menurut hasil wawancara ke tigapuluh informan menyatakan bahwa $42 \%$ penggunaan bantuan PKH digunakan untuk membiayai kebutuhan pendidikan anak, 48\% untuk digunakan untuk menunjang kebutuhan makan keluarga dan 10\% digunakan untuk biaya lain-lain seperti bayar kontrakan, bayar tagihan listrik/air serta untuk modal usaha. Penggunaan terbesar digunakan peserta $\mathrm{PKH}$ untuk menunjang biaya pendidikan anak dan kebutuhan makan keluarga. Penggunaan ini otomatis akan berdampak pada peningkatan kualitas pendidikan dan kesehatan keluarga. Jika dikaji pada aturan penggunaan dana $\mathrm{PKH}$, berdasarkan hasil wawancara tersbut dapat disimpulkan bahwa penggunaan dana PKH tersebut berarti telah digunakan dengan tepat sesuai aturan yang telah disosialisasikan. 


\section{Social Safety Net Pada Program Keluarga Harapan Dalam Meningkatkan Kesejahteraan Keluarga Miskin Di Kota Palembang}

M. Robby Kaharudin

\section{Ketepatan Berpikir}

Di dalam ketepatan berpikir, Dinas Sosial Kota Palembang telah memfasilitasi keberlangsungan UPPKH dan mengontrol bantuan yang diterima KPM, Selain itu Dinas Sosial Kota Palembang juga menjalankan tugasnya dengan melakukan pembinaan dan pertemuan rutin bersama seluruh Pendamping PKH Kota Palembang setiap bulannya. Melalui pertemuan tersebut Dinas Sosial kota Palembang bisa secara langsung menyampaikan setiap arahan dan kebijakan yang bisa disinergikan ke pendamping PKH Kota Palembang. Selain Dinas Sosial Kota Palembang, hal serupa juga dilakukan oleh Pendamping PKH Kota Palembang yang telah melakukan kunjungan rutin untuk memantau peserta $\mathrm{PKH}$ setiap bulannya. Pendamping Program Keluarga Harapan telah berhasil melaksanakan tugas dan fungsinya, dimana terdapat kerja sama antar tenaga kerja tersebut. Ketua Kelompok PKH di Kecamatan Ilir Barat Dua telah menjalankan tugasnya dengan baik serta tercipta kerja sama yang dengan baik dengan pendamping PKH. Sejalan dengan itu, telah terjalin kerja sama antara Dinas Sosial Kota Palembang dan Pendamping PKH Kecamatan Ilir barat dua dan pendamping PKH Kecamatan Ilir barat dua dengan ketua kelompok PKH Kecamatan Ilir Barat Dua. Setiap bulannya pendamping PKH diwajibkan mengikuti rapat bulanan yang diselenggarakan oleh Dinas Sosial kota Palembang.

\section{Analisis Kesejahteraan Dalam ekonomi Islam}

Teori Kesejahteraan dalam Ekonomi Islam tentu berbeda dengan eknomi konvensional. Dalam ekonomi islam indikator kesejahteraan tidak hanya dalam memenuhi kebutuhan hidup didunia saja, namun juga diakhirat. Seperti yang disampaikan pada bab sebelumnya Menurut Ikhwan Abidin Basri, Kesejahteraan ekonomi syariah bertujuan mencapai kesejahteraan manusia secara menyeluruh, yaitu kesejahteraan material, kesejahteraan spiritual dan moral. Konsep ekonomi kesejahteraan syariah bukan saja berdasarkan manifestasi nilai ekonomi, tetapi juga nilai moral dan spiritual, nilai sosial dan nilai politik Islami (Ikhwan abiding basri: 2005) . Menurut Amirus Sodiq dalam jurnalnya menjelaskan bahwa AlQur'an telah menyinggung indikator kesejahteraan dalam Surat Quraisy ayat 3-4 ada tiga, yaitu :

a. Menyembah Tuhan (Pemilik) Ka'bah. Indikator sejahtera yang pertama dan paling utama di dalam Al-Qur'an adalah "Menyembah tuhan (pemilik) 
rumah (Ka'bah)", mengandung makna bahwa proses mensejahterakan masyarakat tersebut didahului dengan pembangunan Tauhid, sehingga sebelum masyarakat sejahtera secara fisik, maka terlebih dahulu dan yang paling utama adalah masyarakat benar-benar menjadikan Allah sebagai pelindung, pengayom dan menyerahkan dirinya sepenuhnya kepada sang khalik. Semua aktivitas kehidupan masyarakat terbingkai dalam aktivitas ibadah (Muhammad Sobary:2007). Dari hasil wawancara ke informan ditemukan bahwa mayoritas informan peserta $\mathrm{PKH}$ ternyata jarang menjalankan kegiatan ibadah wajib seperti sahalat 5 waktu dengan rutin.

Dalam hal ini hasil penelitian menyimpulkan bahwa, menerangkan bahwa dari ke tigapuluh informan yang diwawancarai ada 15 orang (50\%) informan menjawab bahwa jarang melaksanak ibdah shalat lima waktu dalam sehari, 8 informan (27\%) mengakui tidak pernah sama sekali melaksanakan ibadah shalat lima waktu serta 7 informan (23\%) mengakui dirinya rutin melaksanakan ibadah sahalat lima waktu.

Berdasarkan hasil penelitian, ditemukan bahwa 20 informan (67\%) mengakui tidak pernah mengikuti aktivitas pengajian setiap bulannya, 6 informan (20\%) menjawab jarang dan 4 informan (13\%) mengakui dirinya rutin mengikuti kegiatan pengajian atau keagamaan setiap bulannya. Lemahnya tingkat kesadaran dalam beragama ini kedepan akan berpotensi menjadi masalah baru bagi keluarga miskin penerima $\mathrm{PKH}$ di kota Palembang. Karena tidak memiliki pembinaan dalam memenuhi kebutuhan rohani yang memberikan rasa tentram bagi keluarga peserta $\mathrm{PKH}$ tersebut. Padahal Menurut pandangan ekonomi islam, kesejahteraan tidak hanya diukur pada sisi finansial semata yang berorientasi hanya pada urusan dunia tetapi juga harus memiliki orientasi pada akhirat.

b. Menghilangkan lapar, dalam memenuhi kebutuhan makan (untuk menhilangkan rasa lapar) peserta $\mathrm{PKH}$ telah diberikan jaminan bantuan kebutuhan pokok berupa sembako (beras, telur, sayur, dll) oleh pemerintah setiap bulannya melalui program BPNT. Bantuan sembako tersebut diberikan dengan nominal Rp. 200.000,-/bulan berupa saldo e-wallet di kartu ATM PKH yang dimilikinya. Setiap bulan peserta $\mathrm{PKH}$ tersebut menukarkan nya dengan sembako di E-Warung yang dibentuk oleh kementerian sosial.Bantuan tersebut telah memberikan dampak terhadap 


\section{Social Safety Net Pada Program Keluarga Harapan Dalam Meningkatkan Kesejahteraan Keluarga Miskin Di Kota Palembang}

M. Robby Kaharudin

pemenuhan kebutuhan pokok bergizi bagi peserta PKH.Ini dibuktikan dari hasil kesimpulan wawancara yang dilakukan, semua infroman menyatakan setiap hari mengkonsumsi nasi dan mengkonsumsi lauk-pauk yang mengandung gizi.

c. Menghilangkan rasa takut, membuat suasana menjadi aman, nyaman dan tentram bagian dari indikator sejahtera atau tidaknya suatu masyarakat.Jika perampokan, perkosaan, bunuh diri, dan kasus kriminalitas tinggi, maka mengindikasikan bahwa masyarakat tersebut belum sejahtera. Dengan demikian pembentukan pribadi-pribadi yang sholeh dan membuat sistem yang menjaga kesholehan setiap orang bisa terjaga merupakan bagian integral dari proses mensejahterakan masyarakat (M. Hamdar Arraiyyah:2007).

Selain terjaminnya tingkat keamanan keluarga dari kriminalitas indikator ini juga termasuk terjaminnya fasilitas pendidikan dan akses kesehatan; Hasil penelitian juga menyimpulkan bahwa mayoritas peserta $\mathrm{PKH}$ telah merasa aman tinggal dilingkungannya.Begitu juga dalam memenuhi fasilitas pendidikan dan kesehatan.Peserta PKH merasakan tidak begitu sulit dalam mengakses layanan pendidikan dan kesehatan diingkungan tempat tinggalnya.Karena kecamatan Ilir Barat Dua termasuk wilayah yang memiliki fasilitas pendidikan dan kesehatan yang cukup memadahi.Untuk memenuhi kebutuhan pendidikan dan kesehatan juga semua peserta PKH juga menerima bantuan subsidi pendidikan dan kesehatan dari pemerintah. Subsidi pendidikan tersebut berupa Kartu Indonesia Pintar dan Subsidi Kesehatan berupa Kartu Indonesia Sehat yang bisa digunakan untuk berobat.Pada analisa diatas ditemukan bahwa dalam penelitian ini ada dua indikator yang sudah terpenuhi oleh peserta PKH di Kecamatan Ilir barat dua Palembang yaitu indikator 1).Terhilangnya dari rasa lapar; dan 2). Terjaminnya rasa aman nyaman serta terjaminnya fasilitas pendidikan dan kesehatan peserta PKH.Namun Ada satu indokator yang tidak terpenuhi oleh peserta PKH yaitu Indikator agama (religion). Ini dikarenakan $\mathrm{PKH}$ kota Palembang tidak menggunakan Teori kesejahteraan islam dalam mengukur tingat kesejahteraan keluarga miskin di kota Palembang. PKH kota Palembang mengunakan indikator kesejahteraan berdasarkan BPS. Menurut Badan Pusat Statistik (BPS) untuk mengukur kesejahteraan terdiri dari 8 (delapan) indikator; 1).Pendapatan, 2).Pengeluaran, 3).Tempat tinggal, 4).Fasilitas tempat tinggal 5).Kesehatan 
keluarga 6).Kemudahan dalam akses fasilitas kesehatan 7).Kemudahan akses pendidikan dan 8).Kemudahan dalam mendapatkan transportasi. Menurut Kepala sie jaminan sosial dan keluarga dinas sosial kota Palembang, Keluarga sejahtera adalah keluarga yang mandiri dan tidak memiliki ketergantungan bantuan sosial dengan pemerintah, Di Dinas sosial mengukurnya menggunakan indikator BPS, ada 14 indikator penilaian yang digunakan dalam mengukur tingkat kesmiskinan keluarga.

\section{KESIMPULAN}

Dalam penelitian ini dapat disimpulkan bahwa Pelaksanaan program PKH dinilai telah berjalan efektiv sesuai dengan tujuan program. Penggunaan dana Program keluarga harapan $(\mathrm{PKH})$ oleh peserta $\mathrm{PKH}$ telah sesuai digunkan berdasarkan aturan penggunaannya. Mayoritas informan menggunakan dana bantuan tersebut untuk memnuhi kebutuhan biaya pendidikan sepeti membeli sepatu sekolah, buku, pakaian sekolah, iuran pendidikan dll. Sebagian besar lagi juga menggunakannya untuk membeli kebutuhan makanan bergizi yang menunjang kesehatan keluarga, seperti membeli beras, susu anak dan lauk-pauk yang mengandung gizi. PKH juga memiliki dampak terhadap pendidikan dan kesehatan keluarga peserta PKH.Namun pada analisa terhadap kesejahteraan dalam Ekonomi Islam ada dua indikator yang sudah terpenuhi oleh peserta PKH di Kecamatan Ilir barat dua Palembang yaitu indikator 1).Terhilangnya dari rasa lapar; dan 2).Terjaminnya rasa aman nyaman serta terjaminnya fasilitas pendidikan dan kesehatan peserta PKH.Mayoritas informan mengakui telah terpenuhi dalam memenuhi kebutuhan makan yang bergizi, mayoritas informan juga merasa memiliki jaminan dalam menempuh pendidikan dan kesehatan bagi keluarganya.Namun Ada satu indokator yang tidak terpenuhi oleh peserta $\mathrm{PKH}$ yaitu Indikator agama (religion).Mayoritas informan masih banyak yang jarang melaksanakan ibadah wajib seperti shalat 5 waktu dan kegiatan pengajian. Rendahnya tingkat kesadaran dalam menjalankan aktivitas ibadah ini, kedepan akan berpotensi menambah masalah baru bagi keluarga miskin di kota Palembang. Rendahnya indikator agama tersebut juga dikarenakan PKH kota Palembang tidak menggunakan Teori kesejahteraan islam dalam mengukur tingat kesejahteraan keluarga miskin di kota Palembang. PKH kota Palembang mengunakan indikator kesejahteraan berdasarkan BPS. Indikator yang dijadikan 


\section{Social Safety Net Pada Program Keluarga Harapan Dalam Meningkatkan Kesejahteraan Keluarga Miskin Di Kota Palembang}

M. Robby Kaharudin

alat ukur oleh PKH kota Palembang hanya sebatas pemenuhan kebutuhan yang berorientasi pada kelangsungan hidup didunia. Padahal jika merujuk pada teori kesejahteraan dalam persfektif ekonomi islam ada indikator penting yang perlu dijadikan ukuran untuk mengukur tingkat kesejahteraan keluarga, yaitu indikator Religion atau kesadaran beragama.

\section{DAFTAR PUSTAKA}

Abdullah Boedi, 2010, Peradaban Pemikiran Ekonomi Islam, Bandung : Pustaka Setia

Al-Syatibi, Hamka Haq: 2007, Aspek Teologis Konsep Mashlahah dalam Kitab AlMuwafaqat, Jakarta: Erlangga

Badan Pusat Statistik Sumatera Selatan 2018, Kependudukan \& Social, Sumatera selatan : Pelaporan BPS

Deddy Mulyadi, 2015, Studi Kebijakan Publik dan Pelayanan Publik, Bandung: Alfabeta

Direktorat Jaminan Sosial, Direktorat Jenderal Perlindungan dan Jaminan Sosial Kementerian Sosial RI, 2013, Pedoman Umum Program Keluarga Harapan: Ed. Revisi, Kementerian Sosial : Pedum PKH

Edi Suharto, 2015, Jurnal Peran perlindungan sosial dalam mengatasi kemiskinan di Indonesia : Studi kasus Program keluarga harapan, Universitas pasundan bandung : Jurnal

Frederic W. Nalle, Emilia K. Kiha, 2018, Jurnal Dinamika ekonomi pembangunan,UNDIP: Jurnal Ekonomi Pembangunan

Ikhwan Abidin Basri, 2005, Islam dan Pembngunan Ekonomi, Jakarta: Gema Insani Press

M. B. Hendrie Anto, 2003, Pengantar Ekonomika Mikro Islami, Yogyakarta: Ekonesia

Makmur, 2011, Efektivitas Kebijakan Kelembagaan Pengawasan, Bandung : Refika Aditam

Pasolong, Harbani, 2014, Teori Administrasi Publik, Bandung: Alfabeta

Poerwadarminta W.J.S, 1986. Kamus Umum Bahasa Indonesia. Jakarta: Balai Pustaka

P3EI UII, Ekonomi Islam, 2008, Jakarta: RajaGrafindo Persada 
Yusuf al-Qardhawi, 2002, Teologi Kemiskinan: Doktrin Dasar dan Solusi Islam Atas Problem Kemiskinan, Yogyakarta: Mitra Pustaka

Sumodiningrat, gunawan, 1999, pemberdayaan masyarakat dan JPS, Jakarta : Gramedia Pustaka Utama

Subbarao, K. et. All, 1997, Safety net program's and poverty Reduction : Lessons from Cross- Country Experience, Washinton DC : The World Bank

Syaikh Muhammad Abduh, 1999, Tafsir Al-Qur'an Al-Karim (Juz'Amma), diterj.oleh Muhammad Bagir, Tafsir Juz 'Amma Muhammad Abduh, Cetakan V; Bandung: Penerbit Mizan

Tim Nasional percepatan penanggulangan kemiskinan (TNP2K), "Program keluarga harapan”. http://www.tnp2k.go.id diakses pada 15 November 2019

Ulum. Ihyaul MD, 2004, Akuntansi Sektor Publik, Malang ; UMM Press

Warkum Sumito, 2010, Asas-asas Perbankan Islam \& Lembaga-lembaga Terkait. Cet keempat, Jakarta : Raja Grafindo Persada

Yusuf al-Qardhawi, 2002, Teologi Kemiskinan: Doktrin Dasar dan Solusi Islam Atas Problem Kemiskinan Yogyakarta: Mitra Pustaka

\section{Sumber Lain:}

Website Kementerian sosial, 2019, Program keluarga harapanhttps://kemsos.go.id/program-keluarga-harapan-pkh

https://kominfo.go.id/content/detail/15884/presiden-pantau-langsungpenyaluran-pkh-tahap-pertama-tahun-2019/o/artikel gpr

http://staffnew.uny.ac.id/upload/131405899/pendidikan/EKORA+-+JPS.pdf

https://pkh.kemsos.go.id/?pg=detail berita\&id=118

http://e-journal.uajy.ac.id/4241/3/2MHo1723.pdf. 